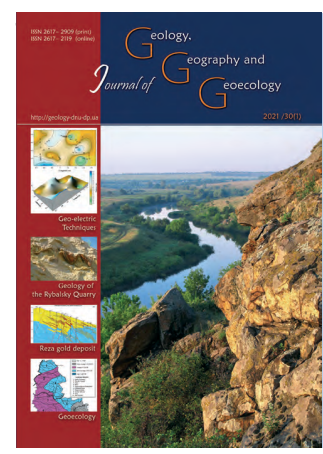

L. V. Nedostrelova

\section{Journal of Geology.} Geography and Geoecology

Journal home page: geology-dnu-dp.ua
ISSN 2617-2909 (print)

ISSN 2617-2119 (online)

Journ.Geol.Geograph.

Geology,

30(1), 133-144.

doi: $10.15421 / 112112$

\title{
Dynamics of snow cover in Kirovohrad region at the end of the $X X$ and the beginning of the XXI centuries
}

\author{
Larysa V. Nedostrelova \\ Odessa State Environmental University, Odessa,Ukraine,nedostrelova@ukr.net
}

Received in revised form: 25.09 .2020

Accepted: 16.10 .2020
Received: 25.08 .2020

Abstract. Snow cover significantly affects the formation of climate in winter. The snow cover has low thermal conductivity, which protects the soil from freezing. In the spring, the snow cover significantly moistens the soil and plays an important role in the surface water regime and in the economic activity of the country. It should be noted that the lack or insufficient height of snow cover can be the cause of freezing of winter crops and their death, which leads to a decrease and even loss of yield. Accordingly, the increase in crop yields depends on the proper use of snow cover. The purpose of the research is to determine the characteristics of the snow cover and analyze their changes in Kirovohrad region in the late twentieth and early twenty-first centuries. Data of daily observations of snow cover at meteorological stations of Kirovohrad region for the period from 1996 to 2018 were used as primary information in the work. It is established that the appearance of snow cover at the stations of Kirovohrad region coincides in two periods (1961-1990 and 1996-2018) and was observed in the third decade of October at almost all stations, except for the area of data distribution of Dolynska weather station, where the first appearance of snow cover during 1961-1990 occurred in the first decade of October. The disappearance of snow in this period was observed in the third decade of April, in contrast to data from the climate cadaster, where $75 \%$ of stations observed snowmelt in the second decade of April, while at Dolynska station in the south of the region snowmelt occurred in the third decade of March. At Kropyvnytskyi station, located in the central part of Kirovohrad region, the appearance and disappearance of snow cover was observed in both periods on the same dates. In the period 1996-2018, the values of the highest decadal peaks for the winter were lower than in the climatic norm. The frequency of winters with the highest decadal height of snow cover in different gradations varies greatly in the study periods. For 1996-2018, the maximum was observed in the gradation of $1-5 \mathrm{~cm}$; in the climatic norm the greatest recurrence is recorded in the gradation of 11-20 cm, significant indicators are observed in the gradation of $21-30 \mathrm{~cm}$. The maximum recurrences of the decadal height of the snow cover are $100 \%$ and are determined in the gradation of $0-5 \mathrm{~cm}$ in both periods of snow cover.

Keywords: snow cover, decadal altitude, spatial variability, time distribution, repeatability

\section{Динаміка снігового покриву на території Кіровоградської області наприкінці XX та на початку XXI століть}

\section{Л.В. Недострелова}

Одеський державний екологічний університет,м. Oдеса, Украӥна,nedostrelova@ukr.net

Анотація. Сніговий покрив істотно впливає в зимовий період на формування клімату. Сніговий покрив має малу теплопровідність, чим зберігає грунт від промерзання. Навесні сніговий покрив суттєво зволожує грунт і грає важливу роль в режимі поверхневих вод і в господарській діяльності країни. Необхідно зазначити, що відсутність чи недостатня висота снігового покриву можуть бути причинами вимерзання озимих посівів та їх загибелі, що зумовлює зниження, i, навіть, втрату врожаю. Відповідно, збільшення врожайності сільськогосподарських культур залежить від належного використання снігового покриву. Метою наукового дослідження є визначення характеристик снігового покриву і аналіз їх змін на території Кіровоградської області наприкінці XX та на початку XXI століть. В якості вихідної інформації в роботі використовувалися дані щоденних спостережень за сніговим покривом на метеорологічних станціях Кіровоградської області за період 31996 по 2018 роки. Встановлено, що поява снігового покриву на станціях Кіровоградської області співпадає за два періоди (19611990 і 1996-2018 рр.) й спостерігається в третій декаді жовтня майже на всіх станціях, винятком є район поширення даних метеостанції Долинська, де поява снігового покриву у період 1961-1990 рр. відбувається в першій декаді жовтня. Схід снігового покриву в цей період відзначається в третій декаді квітня на відміну від даних кліматичного кадастру, де у 75 \% станцій сходження снігу відмічається у другій декаді квітня, а на станції Долинська, що знаходиться на півдні області, схід снігу відбувся взагалі в третій декаді березня. На станції Кропивницький, що знаходиться в центральній частині Кіровоградської 
області, поява і схід снігового покриву відзначається в обидва періоди в ті ж дати. У період 1996-2018 рр. значення найбільших за зиму декадних висот менші, ніж у кліматичній нормі. Повторюваність зим 3 найбільшою декадною висотою снігового покриву у різних градаціях дуже різниться в досліджуванні періоди. Для 1996-2018 років максимум спостерігається в градації 1-5 см; у кліматичній нормі найбільшу повторюваність зафіксовано у градації 11-20 см, значні показники відмічаються і в градації 21-30 см. Максимальні повторюваності декадної висоти снігового покриву дорівнюють 100 \% і визначені в градації 0-5 см в обох періодах на початку й наприкінці періоду зі сніговим покривом.

Ключові слова: сніговий покрив, декадна висота, просторова мінливість, часовий розподіл, повторюваність

\section{Introduction.}

The cold period of the year is characterized by snowfall in the whole territory of Ukraine. In some regions of the country, such as the Carpathians and eastern Polissya, stable cover is maintained for a long time and can reach great heights. In the northeast of the Forest-Steppe, the snow cover is also stable, but its characteristics change rapidly towards the south. In the steppe zone of Ukraine and in its extreme south, a stable snow cover is established in some years and persists for a short period of time. The first snow at the beginning of winter in the country doesn't hold due to the peculiarities of the thermal regime during this period. And subsequent precipitation in the form of snow forms a snow cover which has stable characteristics. An important parameter of snow cover is the nature of its occurrence. A large number of factors depend on the occurrence of snow: air and soil temperature, depth of soil freezing, soil moisture and more. The nature of snow, periods of its formation and dissipation for different regions of Ukraine differ significantly and depend on the terrain, vegetation, circulation, temperature, precipitation, wind, blizzards and more (Handbook of Climate of the USSR, 1969; Lebedenko, 2019).

Kirovohrad region is located in the forest-steppe and steppe physical-geographical zones in central Ukraine, on the interfluve of the Dnieper and the Southern Bug. Agrometeorological, climatic and soil features of the territory are quite favourable for the development of agriculture. The study region lies in the south of the Dnieper Upland. It is a plateau or elevated plain with a dense network of river valleys, ravines and gullies. Kirovograd region is characterized by a temperate continental climate and from southwest to the northeast there is a band of high atmospheric pressure. To the north of it moist air masses spreading from the Atlantic dominate, to the south - continental air masses. Winter is mild and characterized by frequent thaws. The northern and north-western parts of the region lie in a warm but not sufficiently humid agro-climatic zone,; the eastern and southern parts are in a very warm and arid zone. Snow cover is usually formed in the third decade of November, and disappears in the second decade of March (Encyclopedia of
Modern Ukraine, http://esu.com.ua/search_articles. php?id=7021; https://uk.wikipedia.org) .

Snow cover significantly affects the formation of climate in winter. The radiation balance of the underlying surface decreases with the appearance of cover, as snow has significant radiation and reflective properties, which leads to cooling of the surface and air (Aoki, Hachikubo, Hori, 2003). Such characteristics of the snow cover lead to an increase in relative humidity due to a decrease in its temperature and increased humidity during snow evaporation. The snow cover has low thermal conductivity, which protects the soil from freezing. In the spring, the snow cover significantly moistens the soil and plays an important role in the surface water regime and in the economic activity of the country. It should be noted that the lack or insufficient thickness of snow cover can be the cause of freezing of winter crops and their death. Accordingly, the increase in crop yields depends on the proper use of snow cover (USSR Climate Handbook, 1969; Nedostrelova, Lebedenko, 2018; Lebedenko, Nedostrelova, 2019; Goroshko, 2017). Thus, it is difficult to overestimate the importance of snow cover for agriculture, the economy and ecology of the country. The purpose of the research is to identify the characteristics of snow cover and analyze their changes in Kirovohrad region in the late twentieth and early twenty-first centuries.

\section{Material and research methods.}

Data of daily observations of snow cover at meteorological stations of Kirovohrad region for the period from 1996 to 2018 were used as the initial information in the work.

Snow cover is monitored daily, as well as periodically on snow surveys in order to record the amount of snow and water reserves. The term "snow cover" means not only a layer of snow on the surface of the soil, but also layers of ice on the surface of the soil and snow, melted water that appeared under the snow (Instructions, 2011). Observations are carried out at Coordinated International Time at 06 o'clock. Snow monitoring takes place during the season in the presence of snow cover on certain routes. As a result of daily observations, the height of the snow cover on 
the meteorological site or in the selected area near the station, the nature of the snow cover, the degree of snow cover around the station are recorded in points. The height of snow cover is determined by stationary snow stakes as the distance from the soil surface to the boundary of snow cover-atmosphere, the degree of cover, the nature of the snow and the structure of snow are determined visually in all weather conditions. The degree of cover is determined on a 10-point scale. Assessment of the nature of snow cover is based on the presence of snow drifts, as well as the condition of the soil under the snow cover. (Nastanova, 2011).

Snow cover is characterized by decadal heights, calculated at the beginning and end of winter, when snow cover is observed in 50\% of winters and more. Decade height is determined by dividing the total height for all years of the period by the number of years. If snow is detected in less than $50 \%$ of winters, the decadal height is not calculated, and in the table of the handbook a mark (•)is put The multiyear height of snow cover is calculated in the same way as by a snow stake. The height of snow cover, as a rule, varies significantly from year to year, which is why the frequency and occurrence of winters with different maximum decadal heights of snow cover is distinguished. Such calculations are performed only for long-range base stations (Vrublevskaya, Katerusha, Myrotvorskaya, 2004; Kornus, Lysenko, 2017; Nedostrelova, Lebedenko, 2019). An important parameter of snow cover is the long-term maximum height for winter, which is calculated by averaging the maximum decadal altitudes, which are selected from each year, regardless of in which decade or month this maximum is recorded. Maximum and minimum decadal heights by months are determined according to data from a fixed snow stake, and in winter such heights are calculated according to the stakes and snow monitoring (Vrublevskaya, Katerusha, Mirotvorskaya, 2004; Nedostrelova, Lebedenko, 2019).
Snow cover is characterized by certain criteria developed according to the GGO method. According to this method, a day with snow cover is considered a day in which at least half of the visible area of the station is covered with snow. Steady snow cover is cover that is observed for at least a month with breaks of no more than three separate days or days in a row, and a break of one day in early winter corresponds to presence of snow cover for at least 5 days, and a longer break is preceded by snow for at least 10 days. Observations of snow cover show that several periods with steady snow cover may form during the winter. If there are no more than 5 days between such periods, the period from the first day with fixed cover to the last day of winter is fixed as a single period. An important characteristic of the established snow cover is the average long-term dates of formation and dissipation. Such dates are calculated when the number of days with snow cover is more than $50 \%$ of all winters and only one period with stable snow cover was observed during the winter. If at the end of winter no more than 3 days after the snowmelt, snow cover is formed again which lasts at least 10 days, the period of occurrence is recorded as continuous. All defined dates for each year are entered in the table and determine the average dates, the earliest and the latest (Vrublevskaya, Katerusha, Mirotvorskaya, 2004; Nedostrelova, Lebedenko, 2019).

\section{Results and their analysis.}

According to daily observations, the decadal height of snow cover at meteorological stations in Kirovohrad region for the period from 1996 to 2018 was calculated (Table 1, Table 3 ). To identify changes in the height of snow cover in the study area, two climatic periods were used: the first is 1996-2018, the second is the climatic norm (Climatological Standard Norms, 2002) of 1961-1990 (Table 2, Table 4).

Table 1. Decade height $(\mathrm{cm})$ of snow cover on a permanent snow stake for the period 1996-2018.

\begin{tabular}{|c|c|c|c|c|c|c|c|c|c|c|c|c|c|c|c|c|c|c|c|c|c|c|}
\hline \multirow[t]{2}{*}{ Station } & \multirow{2}{*}{$\frac{X}{3}$} & \multicolumn{3}{|c|}{ XI } & \multicolumn{3}{|c|}{ XII } & \multicolumn{3}{|c|}{ I } & \multicolumn{3}{|c|}{ II } & \multicolumn{3}{|c|}{ III } & \multicolumn{3}{|c|}{ IV } & \multicolumn{3}{|c|}{$\begin{array}{c}\text { The greatest for the } \\
\text { winter }\end{array}$} \\
\hline & & 1 & 2 & 3 & 1 & 2 & 3 & 1 & 2 & 3 & 1 & 2 & 3 & 1 & 2 & 3 & 1 & 2 & 3 & aver & $\max$ & $\min$ \\
\hline Svitlovodsk & $\cdot$ & • & • & - & 2 & 3 & 3 & 4 & 6 & 6 & 6 & 5 & 4 & 5 & 4 & $\cdot$ & • & • & $\bullet$ & 11 & 33 & 0 \\
\hline Novomyrhorod & - & - & 2 & 4 & 3 & 4 & 6 & 7 & 9 & 11 & 14 & 11 & 10 & 11 & 9 & 4 & $\cdot$ & $\cdot$ & - & 19 & 43 & 0 \\
\hline Znamyanka & - & - & $\bullet$ & 4 & 3 & 4 & 5 & 6 & 8 & 11 & 12 & 10 & 8 & 11 & 11 & 5 & $\bullet$ & - & $\bullet$ & 19 & 55 & 0 \\
\hline Kropyvnytskyi & $\cdot$ & • & 1 & - & 2 & 3 & 4 & 6 & 7 & 9 & 9 & 7 & 5 & 7 & 7 & 3 & $\bullet$ & $\cdot$ & $\bullet$ & 15 & 37 & 0 \\
\hline Gaivoron & & • & • & 3 & 3 & 5 & 5 & 7 & 9 & 10 & 8 & 10 & 6 & 5 & 3 & 1 & • & $\bullet$ & & 15 & 34 & 0 \\
\hline Pomichna & • & - & • & 3 & 2 & 3 & 4 & 5 & 8 & 10 & 10 & 8 & 6 & 7 & 6 & 2 & $\bullet$ & • & $\bullet$ & 14 & 31 & 0 \\
\hline Dolynska & & • & - & • & $\bullet$ & 3 & 3 & 5 & 6 & 8 & 8 & 8 & 5 & 6 & 5 & • & • & • & & 14 & 37 & 0 \\
\hline Bobrynets & & • & • & - & • & 2 & 3 & 6 & 7 & 11 & 9 & 7 & 7 & 10 & • & - & • & • & & 15 & 39 & 0 \\
\hline
\end{tabular}


Table 2. Decade height $(\mathrm{cm})$ of snow cover on a permanent snow stake for the period 1961-1990.

\begin{tabular}{|c|c|c|c|c|c|c|c|c|c|c|c|c|c|c|c|c|c|c|c|c|c|c|c|c|}
\hline \multirow[t]{2}{*}{ Station } & \multicolumn{3}{|c|}{$X$} & \multicolumn{3}{|c|}{ XI } & \multicolumn{3}{|c|}{ XII } & \multicolumn{3}{|c|}{ I } & \multicolumn{3}{|c|}{ II } & \multicolumn{3}{|c|}{ III } & \multicolumn{3}{|c|}{ IV } & \multicolumn{3}{|c|}{$\begin{array}{l}\text { The greatest for } \\
\text { the winter }\end{array}$} \\
\hline & 1 & 2 & 3 & 1 & 2 & 3 & 1 & 2 & 3 & 1 & 2 & 3 & 1 & 2 & 3 & 1 & 2 & 3 & 1 & 2 & 3 & aver & $\max$ & $\min$ \\
\hline Svitlovodsk & & & • & • & • & 1 & 1 & 3 & 3 & 4 & 6 & 6 & 6 & 7 & 7 & 6 & 3 & • & • & • & & 16 & 59 & 6 \\
\hline Novomyrhorod & & & - & - & • & 2 & 3 & 5 & 6 & 7 & 9 & 10 & 10 & 12 & 12 & 11 & 7 & 4 & • & • & & 24 & 52 & 4 \\
\hline Znamyanka & & & • & - & - & 2 & 3 & 5 & 5 & 6 & 9 & 10 & 11 & 11 & 12 & 11 & 7 & 4 & $\bullet$ & - & & 24 & 63 & 10 \\
\hline Kropyvnytskyi & & & • & • & - & 1 & 3 & 5 & 6 & 6 & 9 & 10 & 11 & 12 & 12 & 12 & 8 & 3 & $\bullet$ & - & $\bullet$ & 28 & 61 & 9 \\
\hline Gaivoron & & & • & • & • & 1 & 2 & 3 & 4 & 6 & 8 & 9 & 8 & 9 & 10 & 7 & 5 & • & $\bullet$ & - & & 23 & 42 & 6 \\
\hline Pomichna & & & • & • & - & 1 & 1 & 3 & 3 & 4 & 6 & 7 & 6 & 6 & 7 & 6 & 4 & 2 & • & $\bullet$ & & 19 & 32 & 6 \\
\hline Dolynska & $\bullet$ & & - & - & - & 1 & 2 & 3 & 3 & 3 & 5 & 8 & 8 & 9 & 10 & 8 & 5 & 2 & & & & 18 & 61 & 5 \\
\hline Bobrynets & & & - & - & - & 1 & 2 & 3 & 3 & 4 & 5 & 6 & 6 & 8 & 9 & 7 & 3 & • & • & • & & 20 & 55 & 4 \\
\hline
\end{tabular}

The appearance of snow cover at the stations of Kirovohrad region in the period 1996-2018 was detected from the third decade of October at almost all stations, except for stations Gaivoron, Dolynska, Bobrynets, where the appearance of snow cover occurs in the first decade of November. The disappearance of snow was determined in the third decade of April, with the exception of the stations Gaivoron, Dolynska, Bobrynets (Table 1). The maximum values of the decadal height of snow cover were observed in the first decade of February. They were 14 and $12 \mathrm{~cm}$ at Novomyrhorod and Znamyanka stations, respectively. The lowest values of altitude were recorded at the beginning and end of the period with snow cover. For each station, the averages were calculated, the minimum and maximum values of this indicator were identified. The maximum average value for winter - $19 \mathrm{~cm}$ was observed at Novomyrhorod and Znamyanka stations, and the minimum $-11 \mathrm{~cm}$ at Svitlovodsk station. The minimum value for all stations was $0 \mathrm{~cm}$. The maximum value $-55 \mathrm{~cm}$ was recorded at Znamyanka station.
The appearance of snow cover at the stations of Kirovohrad region according to the climatic norm was observed from the third decade of October at all stations, except the station Dolynska, where snow appeared in the first decade of October (Table 2). The disappearance of snow in almost all stations can be traced in the second decade of April, except for Kropyvnytskyi station in the third decade of April and Dolynska station in the third decade of March. The maximum values of the average decadal height of snow cover were observed in the second and third decades of February and in the first decade of March and were $12 \mathrm{~cm}$ at the stations Novomyrhorod, Znamyanka and Kropyvnytskyi. The lowest values of altitude were recorded at the beginning and end of the period with snow cover. The maximum average value for winter $-28 \mathrm{~cm}$ was observed at Kropyvnytskyi station, and the minimum $-16 \mathrm{~cm}$ at Svitlovodsk station. The minimum value of $4 \mathrm{~cm}$ was observed at Novomyrhorod and Bobrynets stations. The maximum value - $63 \mathrm{~cm}$ was recorded at Znamyanka station.

Table 3. Recurrence (\%) of winters with the greatest decadal height of snow cover in different grades for the period 1996-2018.

\begin{tabular}{|l|c|c|c|c|c|c|c|c|}
\hline \multirow{2}{*}{ Station } & \multicolumn{7}{|c|}{ Height of snow cover (cm) } \\
\cline { 2 - 10 } & 0 & $1-5$ & $6-10$ & $\begin{array}{c}11- \\
20\end{array}$ & $\begin{array}{c}21- \\
30\end{array}$ & $\begin{array}{c}31- \\
40\end{array}$ & $\begin{array}{c}41- \\
50\end{array}$ & $\begin{array}{c}51- \\
60\end{array}$ \\
\hline Svitlovodsk & 27 & 48 & 17 & 7 & 1 & 0 & & \\
\hline Novomyrhorod & 20 & 39 & 12 & 18 & 8 & 2 & 1 & \\
\hline Znamyanka & 24 & 37 & 16 & 15 & 4 & 2 & 2 & 0 \\
\hline Kropyvnytskyi & 28 & 38 & 16 & 14 & 3 & 1 & & \\
\hline Gaivoron & 18 & 42 & 22 & 13 & 3 & 2 & & \\
\hline Pomichna & 24 & 41 & 16 & 14 & 4 & 1 & & \\
\hline Dolynska & 24 & 44 & 14 & 13 & 3 & 2 & & \\
\hline Bobrynets & 30 & 36 & 12 & 13 & 7 & 2 & & \\
\hline
\end{tabular}


The next characteristic of snow cover, the trends of which were studied for different periods, is the recurrence of winters with the highest decadal height of snow cover in different gradations (Table 3, Table 4). The maximum recurrence was found in the gradation of $1-5 \mathrm{~cm}$ at all stations, the highest value of $48 \%$ was recorded at the station Svitlovodsk, and the minimum was $36 \%$ and determined for the station Bobrynets. Also, a significant number of cases were observed for the height of $0 \mathrm{~cm}$ : a maximum of $30 \%$ was detected at the station Bobrynets, a minimum of $18 \%$ is characterized by the station Gaivoron. At all stations, in almost $100 \%$ of the winters height of snow cover ranged from 0 to $40 \mathrm{~cm}$. And only for Novomyrhorod and Znamyanka stations was the recurrence value $1-2 \%$ for heights of $41-60 \mathrm{~cm}$. observed at the stations Znamyanka, Kropyvnytskyi and Dolynska, in contrast to the period 1996-2018, when such heights were not detected at all.

The characteristic of snow cover can be also the indicator of recurrence of decadal height for decades , which is shown in tables 5-20 for different periods. Analysis of this parameter for Svitlovodsk station (Table 5) shows that the highest recurrence values were observed in the gradation of $0-5 \mathrm{~cm}$ in the third decade of October, in the first and second decades of November and in the first and third decades of April. They are $100 \%$. In the gradation of $6-10 \mathrm{~cm}$, the maximum recurrence was recorded in the third decade of November $-33 \%$. The maximum recurrence in the gradation of $11-20 \mathrm{~cm}-20 \%$ of cases, was observed in the third decade of January and in the first

Table 4. Recurrence (\%) of winters with the highest decadal height of snow cover in different grades for the period 1961-1990.

\begin{tabular}{|l|c|c|c|c|c|c|c|c|c|}
\hline \multirow{2}{*}{ Station } & \multicolumn{8}{|c|}{ Height of snow cover (cm) } \\
\cline { 2 - 12 } & 0 & $1-5$ & $6-10$ & $11-20$ & $21-30$ & $31-40$ & $41-50$ & $51-60$ & $61-70$ \\
\hline Svitlovodsk & & & 35 & 49 & 10 & 3 & & 3 & \\
\hline Novomyrhorod & & 3 & 3 & 42 & 25 & 14 & 10 & 3 & \\
\hline Znamyanka & & & 10 & 28 & 53 & 3 & & 3 & 3 \\
\hline Kropyvnytskyi & & & 14 & 14 & 39 & 17 & 10 & 3 & 3 \\
\hline Gaivoron & & & 14 & 34 & 28 & 21 & 3 & & \\
\hline Pomichna & & & 14 & 45 & 31 & 10 & & & \\
\hline Dolynska & & 4 & 17 & 50 & 17 & 8 & & & 4 \\
\hline Bobrynets & & 3 & 3 & 63 & 10 & 18 & & 3 & \\
\hline
\end{tabular}

In the period 1961-1990, the maximum recurrence was found in the gradation of $11-20 \mathrm{~cm}$ in $75 \%$ of stations in the study region, the highest value of $63 \%$ was recorded at Bobrynets station, and the minimum was $14 \%$ determined for Kropyvnytskyi station. Also, a significant number of cases were observed for heights of $21-30 \mathrm{~cm}$ : a maximum of $53 \%$ was detected at Znamyanka station, a minimum of $10 \%$ at Svitlovodsk and Bobrynets stations. The maximum gradation of $61-70 \mathrm{~cm}$, which records a recurrence of $3-4 \%$, was decade of March . The highest recurrence - $9 \%$ in the gradation of 21-30 cm was observed in the first decade of February. It should be noted that the value of height in the gradation of $31-50 \mathrm{~cm}$ was recorded only in the second decade of February, when the recurrence was $5 \%$. The appearance of snow cover was observed in the third decade of October, and the disappearance was detected in the third decade of April.

According to the climatic cadastre, the appearance of snow cover at the Svitlovodsk station (Table 6)

Table 5. Recurrence of the decadal height of snow cover by decades at the Svitlovodsk station for the period 1996-2018 (\%)

\begin{tabular}{|c|c|c|c|c|c|c|c|c|c|c|c|c|c|c|c|c|c|c|c|}
\hline \multirow[t]{2}{*}{ Gradation } & \multirow{2}{*}{$\frac{X}{3}$} & \multicolumn{3}{|c|}{ XI } & \multicolumn{3}{|c|}{ XII } & \multicolumn{3}{|c|}{ I } & \multicolumn{3}{|c|}{ II } & \multicolumn{3}{|c|}{ III } & \multicolumn{3}{|c|}{ IV } \\
\hline & & 1 & 2 & 3 & 1 & 2 & 3 & 1 & 2 & 3 & 1 & 2 & 3 & 1 & 2 & 3 & 1 & 2 & 3 \\
\hline $0-5$ & 100 & 100 & 100 & 67 & 85 & 81 & 75 & 67 & 60 & 66 & 59 & 76 & 72 & 67 & 72 & 91 & 100 & & 100 \\
\hline $6-10$ & & & & 33 & 15 & 19 & 25 & 22 & 25 & 14 & 27 & 9 & 11 & 13 & 14 & 9 & & & \\
\hline $11-20$ & & & & & & & & 11 & 10 & 20 & 5 & 5 & 17 & 20 & 14 & & & & \\
\hline $21-30$ & & & & & & & & & 5 & & 9 & 5 & & & & & & & \\
\hline $31-50$ & & & & & & & & & & & & 5 & & & & & & & \\
\hline
\end{tabular}


Table 6. Recurrence of the decadal height of snow cover by decades at the Svitlovodsk station for the period 1961-1990 (\%)

\begin{tabular}{|c|c|c|c|c|c|c|c|c|c|c|c|c|c|c|c|c|c|c|}
\hline \multirow[t]{2}{*}{ Gradation } & \multirow{2}{*}{$\begin{array}{l}\mathrm{X} \\
3\end{array}$} & \multicolumn{3}{|c|}{ XI } & \multicolumn{3}{|c|}{ XII } & \multicolumn{3}{|c|}{ I } & \multicolumn{3}{|c|}{ II } & \multicolumn{3}{|c|}{ III } & \multicolumn{2}{|c|}{ IV } \\
\hline & & 1 & 2 & 3 & 1 & 2 & 3 & 1 & 2 & 3 & 1 & 2 & 3 & 1 & 2 & 3 & 1 & 2 \\
\hline $0-5$ & 100 & 100 & 100 & 100 & 100 & 82 & 75 & 84 & 70 & 62 & 68 & 58 & 56 & 57 & 79 & 75 & 100 & 100 \\
\hline $6-10$ & & & & & & 11 & 14 & 4 & 21 & 26 & 21 & 19 & 16 & 17 & 5 & 17 & & \\
\hline $11-20$ & & & & & & 7 & 11 & 4 & 3 & 4 & 7 & 15 & 20 & 17 & 5 & 8 & & \\
\hline $21-30$ & & & & & & & & 4 & 3 & 4 & & 4 & 8 & 9 & 11 & & & \\
\hline $31-50$ & & & & & & & & 4 & 3 & 4 & 4 & 4 & & & & & & \\
\hline
\end{tabular}

was detected in the third decade of October, as in the period 1996-2018. The disappearance was observed in the second decade of April, which occurred a decade earlier than in the first period. The analysis shows that the maximum recurrence was observed in the gradation of $0-5 \mathrm{~cm}$ in the third decade of October, in the first, second and third decades of November, the first decade of December and in the first and second decades of April. It is $100 \%$. The maximum height was in the gradation of $31-50 \mathrm{~cm}$ and was fixed from the first decade of January to the second decade of February and in almost all these decades was equal to $4 \%$.

A comparative analysis of the two periods shows that the appearance of snow cover at the Svitlovodsk station coincides and is observed in the third decade of October. The disappearance of snow cover is different - according to climatic norms it was recorded in the second decade of April, and for the period 1996-2018 it was observed in the third decade of April. Maximum recurrences of $100 \%$ were observed in the gradation of $0-5 \mathrm{~cm}$ in both periods, but can be observed in different decades. The maximum height is defined in the gradation of $31-50 \mathrm{~cm}$, but is fixed in different decades for certain periods. in the first decade of January - $28 \%$. The maximum recurrence in the gradation $11-20 \mathrm{~cm}-27 \%$ of cases was in the first decade of February. The highest recurrence $-26 \%$ in the gradation of $21-30 \mathrm{~cm}$ was observed in the third decade of January. It is possible to note that in a gradation of $31-50 \mathrm{~cm}$ the maximum of recurrence was $12 \%$ in the first and second decades of March.

The appearance of snow cover occurred in both periods in the third decade of October (Table 7, Table 8 ), and the decline was observed according to climatic norms a decade earlier than in the period 19962018 , in the second decade of April. The maximum recurrence in the period 1961-1990 was also observed in the gradation of $0-5 \mathrm{~cm}$, but in the third decade of October, in the first decade of November, in the first and second decades of April and was $100 \%$. The greatest height was observed in the gradation of 31$50 \mathrm{~cm}$, recorded from the third decade of December to the second decade of March and ranged from 3 to $18 \%$ in contrast to the first period, when such heights were detected in the first two decades of February and March with recurrence values from 8 up to $12 \%$.

At Znamyanka station, the highest recurrence values were observed in the gradation of $0-5 \mathrm{~cm}$ in

Table 7. Recurrence of the decadal height of snow cover by decades at the station Novomyrhorod for the period 1996-2018 (\%)

\begin{tabular}{|c|c|c|c|c|c|c|c|c|c|c|c|c|c|c|c|c|c|c|c|}
\hline \multirow[t]{2}{*}{ Gradation } & $X$ & \multicolumn{3}{|c|}{$\mathrm{XI}$} & \multicolumn{3}{|c|}{ XII } & \multicolumn{3}{|c|}{ I } & \multicolumn{3}{|c|}{ II } & \multicolumn{3}{|c|}{ III } & \multicolumn{3}{|c|}{ IV } \\
\hline & 3 & 1 & 2 & 3 & 1 & 2 & 3 & 1 & 2 & 3 & 1 & 2 & 3 & 1 & 2 & 3 & 1 & 2 & 3 \\
\hline $0-5$ & 100 & 100 & 84 & 77 & 78 & 77 & 66 & 39 & 55 & 39 & 27 & 53 & 45 & 52 & 56 & 82 & 100 & 100 & 100 \\
\hline $6-10$ & & & 8 & 8 & 11 & 6 & 10 & 28 & 15 & 9 & 22 & 9 & 20 & 6 & 13 & 6 & & & \\
\hline $11-20$ & & & 8 & 15 & 11 & 17 & 24 & 22 & 20 & 26 & 27 & 13 & 15 & 24 & 19 & 6 & & & \\
\hline $21-30$ & & & & & & & & 11 & 10 & 26 & 14 & 17 & 20 & 6 & & 6 & & & \\
\hline $31-50$ & & & & & & & & & & & 10 & 8 & & 12 & 12 & & & & \\
\hline
\end{tabular}

For Novomyrhorod station, the highest values of recurrence were observed in the gradation of $0-5$ $\mathrm{cm}$ in the third decade of October, in the first decade of November and from the first to the third decades of April. They are $100 \%$ (Table 7). In the gradation of $6-10 \mathrm{~cm}$, the maximum recurrence was recorded the third decade of October, in the first decade of November and from the first to the third decade of April and are 100\% (Table 9). In the gradation of 6-10 $\mathrm{cm}$, the maximum recurrence was recorded in the first decade of January - $42 \%$. The maximum recurrence for the gradation of $11-20 \mathrm{~cm}-38 \%$ of cases was in 
Table 8. Recurrence of the decadal height of snow cover by decades at the station Novomyrhorod for the period 1961-1990 (\%)

\begin{tabular}{|c|c|c|c|c|c|c|c|c|c|c|c|c|c|c|c|c|c|c|}
\hline \multirow[t]{2}{*}{ Gradation } & X & \multicolumn{3}{|c|}{ XI } & \multicolumn{3}{|c|}{ XII } & \multicolumn{3}{|c|}{ I } & \multicolumn{3}{|c|}{ II } & \multicolumn{3}{|c|}{ III } & \multicolumn{2}{|c|}{ IV } \\
\hline & 3 & 1 & 2 & 3 & 1 & 2 & 3 & 1 & 2 & 3 & 1 & 2 & 3 & 1 & 2 & 3 & 1 & 2 \\
\hline $0-5$ & 100 & 100 & 74 & 83 & 71 & 50 & 53 & 48 & 52 & 33 & 53 & 36 & 27 & 27 & 55 & 79 & 100 & 100 \\
\hline $6-10$ & & & 13 & 17 & 19 & 46 & 32 & 28 & 28 & 29 & 7 & 25 & 23 & 27 & 15 & 5 & & \\
\hline $11-20$ & & & 13 & & 10 & & 7 & 16 & 3 & 19 & 25 & 21 & 30 & 28 & 15 & 5 & & \\
\hline $21-30$ & & & & & & 4 & 4 & 4 & 14 & 15 & 11 & 7 & 8 & & 5 & 11 & & \\
\hline $31-50$ & & & & & & & 4 & 4 & 3 & 4 & 4 & 11 & 12 & 18 & 10 & & & \\
\hline
\end{tabular}

the first decade of February. The highest recurrence $-12 \%$ in the gradation of $21-30 \mathrm{~cm}$ was observed in the first decade of March. The maximum recurrence of the gradation of $31-50 \mathrm{~cm}, 12 \%$, was also in the first decade of March. It should be noted that at this station, in contrast to the previous two, the maximum height of snow cover was in the gradation of 51-75 $\mathrm{cm}$ in the second decade of March, the frequency of which was $7 \%$. the gradation of $0-5 \mathrm{~cm}$ was observed only in the third decade of October and in the second decade of April and was $100 \%$ (Table 10).

Analysis of the frequency of decadal height at Kropyvnytskyi station shows that the highest values of recurrence were observed in the gradation of 0-5 $\mathrm{cm}$ in the third decade of October and in the first decade of November and from the first to the third decades of April. They are 100\% (Table 11). In the

Table 9. Recurrence of the decadal height of snow cover by decades at Znamyanka station for the period 1996-2018 (\%)

\begin{tabular}{|c|c|c|c|c|c|c|c|c|c|c|c|c|c|c|c|c|c|c|c|}
\hline \multirow[t]{2}{*}{ Gradation } & X & \multicolumn{3}{|c|}{ XI } & \multicolumn{3}{|c|}{ XII } & \multicolumn{3}{|c|}{ I } & \multicolumn{3}{|c|}{ II } & \multicolumn{3}{|c|}{ III } & \multicolumn{3}{|c|}{ IV } \\
\hline & 3 & 1 & 2 & 3 & 1 & 2 & 3 & 1 & 2 & 3 & 1 & 2 & 3 & 1 & 2 & 3 & 1 & 2 & 3 \\
\hline $0-5$ & 100 & 100 & 80 & 66 & 75 & 75 & 72 & 48 & 55 & 42 & 28 & 54 & 61 & 59 & 46 & 79 & 100 & 100 & 100 \\
\hline $6-10$ & & & 20 & 17 & 19 & 13 & 13 & 42 & 15 & 19 & 19 & 14 & 16 & 6 & 27 & 14 & & & \\
\hline $11-20$ & & & & 17 & 6 & 12 & 10 & 10 & 25 & 24 & 38 & 23 & 12 & 11 & 13 & & & & \\
\hline $21-30$ & & & & & & & 5 & & 5 & 10 & 5 & & 6 & 12 & & & & & \\
\hline $31-50$ & & & & & & & & & & 5 & 10 & 9 & 5 & 12 & 7 & 7 & & & \\
\hline $51-75$ & & & & & & & & & & & & & & & 7 & & & & \\
\hline
\end{tabular}

In the period 1961-1990, similar maximum heights were also recorded, but from the second decade of February to the second decade of March. The recurrence ranged from $4-9 \%$ (Table 10). The appearance of snow cover was recorded in the third decade of October in both periods. The disappearance was observed in the second decade of April in the period 1961-1990, which is one decade earlier than in the period 1996-2018. The maximum recurrence in gradation of 6-10 $\mathrm{cm}$, the maximum recurrence was recorded in the first decade of January - 38\%. The maximum recurrence in the gradation $11-20 \mathrm{~cm}, 34 \%$ of cases, was in the third decade of January. The highest recurrence in the gradation of $21-30 \mathrm{~cm}, 10 \%$ ,was observed in the second decade of February. In the gradation $31-50 \mathrm{~cm}$, the maximum was fixed in the second decade of February, where the recurrence was $8 \%$. The appearance of snow cover was recorded

Table 10. Recurrence of the decadal height of snow cover by decades at the Znamyanka station for the period 1961-1990 (\%)

\begin{tabular}{|c|c|c|c|c|c|c|c|c|c|c|c|c|c|c|c|c|c|c|}
\hline \multirow[t]{2}{*}{ Gradation } & \multirow{2}{*}{$\frac{X}{3}$} & \multicolumn{3}{|c|}{ XI } & \multicolumn{3}{|c|}{ XII } & \multicolumn{3}{|c|}{ I } & \multicolumn{3}{|c|}{ II } & \multicolumn{3}{|c|}{ III } & \multicolumn{2}{|c|}{ IV } \\
\hline & & 1 & 2 & 3 & 1 & 2 & 3 & 1 & 2 & 3 & 1 & 2 & 3 & 1 & 2 & 3 & 1 & 2 \\
\hline $0-5$ & 100 & 86 & 80 & 85 & 76 & 43 & 60 & 44 & 43 & 32 & 36 & 39 & 31 & 39 & 69 & 63 & 66 & 100 \\
\hline $6-10$ & & 14 & 20 & 10 & 14 & 38 & 29 & 36 & 25 & 25 & 25 & 25 & 23 & 19 & 9 & 16 & 17 & \\
\hline $11-20$ & & & & 5 & 10 & 19 & 7 & 16 & 21 & 32 & 25 & 21 & 23 & 30 & 9 & 16 & 17 & \\
\hline $21-30$ & & & & & & & 4 & 4 & 7 & 7 & 7 & 7 & 19 & 4 & 4 & & & \\
\hline $31-50$ & & & & & & & & & 4 & 4 & 7 & 4 & & 4 & & 5 & & \\
\hline $51-75$ & & & & & & & & & & & & 4 & 4 & 4 & 9 & & & \\
\hline
\end{tabular}


in the third decade of October, the disappearance was observed in the third decade of April at the station for both periods (Table 11, Table 12).
$40 \%$. The maximum recurrence in the gradation $11-$ $20 \mathrm{~cm}-33 \%$ of cases, was in the second decade of January . The highest recurrence in the gradation of

Table 11. Recurrence of the decadal height of snow cover by decades at Kropyvnytskyi station for the period 1996-2018 (\%)

\begin{tabular}{|c|c|c|c|c|c|c|c|c|c|c|c|c|c|c|c|c|c|c|c|}
\hline \multirow[t]{2}{*}{ Gradation } & \multirow{2}{*}{$\frac{X}{3}$} & \multicolumn{3}{|c|}{ XI } & \multicolumn{3}{|c|}{ XII } & \multicolumn{3}{|c|}{ I } & \multicolumn{3}{|c|}{ II } & \multicolumn{3}{|c|}{ III } & \multicolumn{3}{|c|}{ IV } \\
\hline & & 1 & 2 & 3 & 1 & 2 & 3 & 1 & 2 & 3 & 1 & 2 & 3 & 1 & 2 & 3 & 1 & 2 & 3 \\
\hline $0-5$ & 100 & 100 & 92 & 64 & 83 & 77 & 72 & 52 & 50 & 49 & 45 & 65 & 71 & 59 & 69 & 82 & 100 & 100 & 100 \\
\hline $6-10$ & & & & 9 & 11 & 17 & 18 & 38 & 22 & 9 & 31 & 13 & 10 & 12 & 13 & 6 & & & \\
\hline $11-20$ & & & 8 & 27 & 6 & 6 & 10 & 10 & 18 & 34 & 10 & 10 & 14 & 23 & 6 & 12 & & & \\
\hline $21-30$ & & & & & & & & & 10 & 8 & 9 & 4 & 5 & & 6 & & & & \\
\hline $31-50$ & & & & & & & & & & & 5 & 8 & & 6 & 6 & & & & \\
\hline
\end{tabular}

Maximum recurrences were observed in the gradation of $0-5 \mathrm{~cm}$ in the third decade of October, in the first decade of November, from the first to the third decade of April and were $100 \%$ for these periods. It should be noted that the maximum height was recorded in the gradation of 51-75 $\mathrm{cm}$, and was fixed only in the third decade of February and was equal to $4 \%$ only according to climatic norms.
$21-30 \mathrm{~cm}-12 \%$, was observed in the second decade of February. The gradation of $31-35 \mathrm{~cm}$ had a maximum recurrence of $9 \%$ in the third decade of January. The appearance of snow cover was recorded in the first decade of February, which is one decade later than in the period 1961-1990 (Table 13, Table 14). The disappearance was observed in the second decade of April in both periods. The maximum recurrence was

Table 12. Recurrence of the decade height of snow cover by decades at Kropyvnytskyi station for the period 1961-1990 (\%)

\begin{tabular}{|c|c|c|c|c|c|c|c|c|c|c|c|c|c|c|c|c|c|c|c|}
\hline \multirow[t]{2}{*}{ Gradation } & $\mathrm{X}$ & \multicolumn{3}{|c|}{$\mathrm{XI}$} & \multicolumn{3}{|c|}{ XII } & \multicolumn{3}{|c|}{ I } & \multicolumn{3}{|c|}{ II } & \multicolumn{3}{|c|}{ III } & \multicolumn{3}{|c|}{ IV } \\
\hline & 3 & 1 & 2 & 3 & 1 & 2 & 3 & 1 & 2 & 3 & 1 & 2 & 3 & 1 & 2 & 3 & 1 & 2 & 3 \\
\hline $0-5$ & 100 & 100 & 89 & 94 & 66 & 61 & 59 & 52 & 54 & 39 & 40 & 35 & 33 & 35 & 57 & 76 & 100 & 100 & 100 \\
\hline $6-10$ & & & 11 & & 17 & 27 & 19 & 20 & 21 & 25 & 14 & 29 & 29 & 17 & 5 & 6 & & & \\
\hline $11-20$ & & & & 6 & 11 & 8 & 15 & 20 & 11 & 25 & 28 & 14 & 8 & 17 & 14 & 12 & & & \\
\hline $21-30$ & & & & & 6 & 4 & 7 & 8 & 7 & 4 & 11 & 11 & 13 & 9 & 10 & 6 & & & \\
\hline $31-50$ & & & & & & & & & 7 & 7 & 7 & 11 & 13 & 22 & 14 & & & & \\
\hline $51-75$ & & & & & & & & & & & & & 4 & & & & & & \\
\hline
\end{tabular}

At Gaivoron station, the analysis of the time distribution of the recurrence of the decadal height of snow cover shows that the largest values of this indicator were observed in the gradation of $0-5 \mathrm{~cm}$ in the first decade of November and from the first to the second decade of April. They were 100\% (Table 13). In the gradation of $6-10 \mathrm{~cm}$, the maximum recurrence was recorded in the second decade of December - observed in the gradation of $0-5 \mathrm{~cm}$ and was $100 \%$, but can be observed in different decades. It can be noted that the maximum height was recorded in the gradation of $31-50 \mathrm{~cm}$ for both periods, was fixed in different decades and ranged from 4 to $9 \%$.

Analysis of the frequency of decadal height for the period 1996-2018 at Pomichna station shows that the highest values were observed in the gradation of

Table 13. Recurrence of the decadal height of snow cover by decades at Gaivoron station for the period 1996-2018 (\%)

\begin{tabular}{|c|c|c|c|c|c|c|c|c|c|c|c|c|c|c|c|c|c|}
\hline \multirow[t]{2}{*}{ Gradation } & \multicolumn{3}{|c|}{ XI } & \multicolumn{3}{|c|}{ XII } & \multicolumn{3}{|c|}{ I } & \multicolumn{3}{|c|}{ II } & \multicolumn{3}{|c|}{ III } & \multicolumn{2}{|c|}{ IV } \\
\hline & 1 & 2 & 3 & 1 & 2 & 3 & 1 & 2 & 3 & 1 & 2 & 3 & 1 & 2 & 3 & 1 & 2 \\
\hline $0-5$ & 100 & 86 & 75 & 84 & 53 & 65 & 47 & 22 & 48 & 50 & 41 & 45 & 79 & 75 & 93 & 100 & 100 \\
\hline $6-10$ & & & 17 & 8 & 40 & 23 & 37 & 39 & 17 & 27 & 12 & 33 & & 25 & 7 & & \\
\hline $11-20$ & & 14 & 8 & 8 & & 12 & 11 & 33 & 22 & 14 & 30 & 22 & 14 & & & & \\
\hline $21-30$ & & & & & 7 & & 5 & 6 & 4 & 9 & 12 & & 7 & & & & \\
\hline $31-50$ & & & & & & & & & 9 & & 5 & & & & & & \\
\hline
\end{tabular}


Table 14. Recurrence of the decadal height of snow cover by decades at Gaivoron station for the period 1961-1990 (\%)

\begin{tabular}{|c|c|c|c|c|c|c|c|c|c|c|c|c|c|c|c|c|c|c|}
\hline \multirow[t]{2}{*}{ Gradation } & X & \multicolumn{3}{|c|}{ XI } & \multicolumn{3}{|c|}{ XII } & \multicolumn{3}{|c|}{ I } & \multicolumn{3}{|c|}{ II } & \multicolumn{3}{|c|}{ III } & \multicolumn{2}{|c|}{ IV } \\
\hline & 3 & 1 & 2 & 3 & 1 & 2 & 3 & 1 & 2 & 3 & 1 & 2 & 3 & 1 & 2 & 3 & 1 & 2 \\
\hline $0-5$ & 100 & 100 & 87 & 93 & 81 & 80 & 69 & 52 & 52 & 48 & 50 & 61 & 44 & 37 & 66 & 69 & 75 & 80 \\
\hline $6-10$ & & & & 7 & 6 & 12 & 15 & 20 & 12 & 11 & 8 & 7 & 20 & 35 & 14 & 23 & 25 & 20 \\
\hline $11-20$ & & & 13 & & 13 & 8 & 12 & 16 & 12 & 30 & 27 & 11 & 4 & 5 & 10 & 8 & & \\
\hline $21-30$ & & & & & & & 4 & 12 & 20 & 11 & 15 & 14 & 28 & 18 & 10 & & & \\
\hline $31-50$ & & & & & & & & & 4 & & & 7 & 4 & 5 & & & & \\
\hline
\end{tabular}

$0-5 \mathrm{~cm}$ in the third decade of October, in the first and second decades of November and from the first to the third decade of April. They were 100\% (Table 15). In the gradation of $6-10 \mathrm{~cm}$, the maximum recurrence was recorded in the first decade of January $-30 \%$. The maximum recurrence in the gradation of $11-20 \mathrm{~cm}-$ $33 \%$ of cases, came in the third decade of January. The highest recurrence $-12 \%$, in the gradation of 21-30 cm was observed in the first decade of March. of January to the second decade of March in the period 1961-1990. This characteristic for the later period was in the gradation of $31-50 \mathrm{~cm}$.

For Dolynska station, the highest values of recurrence were observed in the gradation of $0-5 \mathrm{~cm}$ in the first and second decades of November and in the first decade of April. They were 100\% (Table 17). In the gradation of 6-10 $\mathrm{cm}$, the maximum recurrence was recorded in the first decade of January - 30\%. The

Table 15. Recurrence of the decadal height of snow cover by decades at the Pomichna station for the period 1996-2018 (\%)

\begin{tabular}{|c|c|c|c|c|c|c|c|c|c|c|c|c|c|c|c|c|c|c|c|}
\hline \multirow[t]{2}{*}{ Gradation } & $\mathrm{X}$ & \multicolumn{3}{|c|}{ XI } & \multicolumn{3}{|c|}{ XII } & \multicolumn{3}{|c|}{ I } & \multicolumn{3}{|c|}{ II } & \multicolumn{3}{|c|}{ III } & \multicolumn{3}{|c|}{ IV } \\
\hline & 3 & 1 & 2 & 3 & 1 & 2 & 3 & 1 & 2 & 3 & 1 & 2 & 3 & 1 & 2 & 3 & 1 & 2 & 3 \\
\hline $0-5$ & 100 & 100 & 100 & 84 & 92 & 82 & 69 & 60 & 58 & 43 & 41 & 59 & 60 & 59 & 58 & 79 & 100 & 100 & 100 \\
\hline $6-10$ & & & & 8 & 8 & 12 & 26 & 30 & 22 & 14 & 23 & 14 & 15 & 12 & 17 & 14 & & & \\
\hline $11-20$ & & & & 8 & & 6 & 5 & 10 & 10 & 33 & 22 & 18 & 20 & 17 & 25 & 7 & & & \\
\hline $21-30$ & & & & & & & & & 5 & 10 & 9 & 9 & 5 & 12 & & & & & \\
\hline $31-50$ & & & & & & & & & 5 & & 5 & & & & & & & & \\
\hline
\end{tabular}

The gradation of $31-50 \mathrm{~cm}$ was recorded only in the second decade of January and in the first decade of February with a recurrence of $5 \%$. The appearance of snow cover was recorded in the third decade of October in both periods (Table 15, Table 16). The disappearance was observed in the third decade of April in the period 1996-2018, which is one decade later than according to the climate cadastre. The maximum recurrence was observed in the gradation of $0-5 \mathrm{~cm}$ and was $100 \%$, but it can be observed in different decades. The maximum height was recorded in the gradation of $21-30 \mathrm{~cm}$ from the second decade maximum recurrence of the gradation of 11-20 $\mathrm{cm}$ $23 \%$ of cases, was in the third decade of January. The highest recurrence - $9 \%$, in the gradation of $21-30 \mathrm{~cm}$ was observed in the third decade of January and in the first decade of February. The gradation of 31-50 $\mathrm{cm}$ was fixed only in the first and second decades of February.

The appearance of snow cover was recorded in the first decade of November, which occurred a month later than according to climatic norms (Table 18). The disappearance was observed in the first decade of April, two decades earlier than in the period 1961-

Table 16. Recurrence of the decadal height of snow cover by decades at the Pomichna station for the period 1961-1990 (\%)

\begin{tabular}{|c|c|c|c|c|c|c|c|c|c|c|c|c|c|c|c|c|c|c|}
\hline \multirow[t]{2}{*}{ Gradation } & $\mathrm{X}$ & \multicolumn{3}{|c|}{ XI } & \multicolumn{3}{|c|}{ XII } & \multicolumn{3}{|c|}{ I } & \multicolumn{3}{|c|}{ II } & \multicolumn{3}{|c|}{ III } & \multicolumn{2}{|c|}{ IV } \\
\hline & 3 & 1 & 2 & 3 & 1 & 2 & 3 & 1 & 2 & 3 & 1 & 2 & 3 & 1 & 2 & 3 & 1 & 2 \\
\hline $0-5$ & 100 & 100 & 86 & 100 & 95 & 81 & 78 & 71 & 57 & 55 & 57 & 57 & 48 & 48 & 69 & 82 & 100 & 100 \\
\hline $6-10$ & & & 14 & & 5 & 19 & 15 & 22 & 18 & 19 & 21 & 18 & 20 & 34 & 5 & 18 & & \\
\hline $11-20$ & & & & & & & 7 & 7 & 21 & 22 & 18 & 18 & 28 & 9 & 21 & & & \\
\hline $21-30$ & & & & & & & & & 4 & 4 & 4 & 7 & 4 & 9 & 5 & & & \\
\hline
\end{tabular}


Table 17. Recurrence of the decadal height of snow cover by decades at Dolynska station for the period 1996-2018 (\%)

\begin{tabular}{|c|c|c|c|c|c|c|c|c|c|c|c|c|c|c|c|c|}
\hline \multirow{2}{*}{ Gradation } & \multicolumn{3}{|c|}{ XI } & \multicolumn{3}{|c|}{ XII } & \multicolumn{3}{|c|}{ I } & \multicolumn{3}{|c|}{ II } & \multicolumn{3}{|c|}{ III } & IV \\
\cline { 2 - 17 } & 1 & 2 & 3 & 1 & 2 & 3 & 1 & 2 & 3 & 1 & 2 & 3 & 1 & 2 & 3 & 1 \\
\hline $0-5$ & 100 & 100 & 80 & 82 & 93 & 94 & 60 & 60 & 45 & 48 & 69 & 72 & 75 & 65 & 80 & 100 \\
\hline $6-10$ & & & 20 & 18 & & & 30 & 20 & 23 & 17 & 5 & 6 & & 14 & 20 & \\
\hline $11-20$ & & & & & 7 & 6 & 10 & 20 & 23 & 22 & 16 & 22 & 19 & 21 & & \\
\hline $21-30$ & & & & & & & & & 9 & 9 & 5 & & 6 & & & \\
\hline $31-50$ & & & & & & & & & & 4 & 5 & & & & & \\
\hline
\end{tabular}

1990. The maximum recurrence is observed in the in the first and second decades of November and in gradation of $0-5 \mathrm{~cm}$ and is $100 \%$, but was observed in the first decade of April. They were $100 \%$ (Table 19). different decades. The maximum height was recorded In the gradation of 6-10 cm, the maximum recurrence

Table 18. Recurrence of the decadal height of snow cover by decades at Dolynska station for the period 1961-1990 (\%)

\begin{tabular}{|c|c|c|c|c|c|c|c|c|c|c|c|c|c|c|c|c|c|c|c|c|c|}
\hline \multirow{2}{*}{$\begin{array}{l}\text { Gra- } \\
\text { dation }\end{array}$} & \multicolumn{3}{|c|}{ X } & \multicolumn{3}{|c|}{ XI } & \multicolumn{3}{|c|}{ XII } & \multicolumn{3}{|c|}{ I } & \multicolumn{3}{|c|}{ II } & \multicolumn{3}{|c|}{ III } & \multicolumn{3}{|c|}{ IV } \\
\hline & 1 & 2 & 3 & 1 & 2 & 3 & 1 & 2 & 3 & 1 & 2 & 3 & 1 & 2 & 3 & 1 & 2 & 3 & 1 & 2 & 3 \\
\hline $0-5$ & 100 & & 100 & 100 & 100 & 83 & 80 & 81 & 76 & 70 & 57 & 50 & 48 & 48 & 32 & 48 & 63 & 84 & 100 & 100 & 100 \\
\hline $6-10$ & & & & & & 17 & 20 & 14 & 19 & 20 & 30 & 27 & 30 & 26 & 26 & 19 & 6 & 8 & & & \\
\hline $11-20$ & & & & & & & & 5 & 5 & 10 & 9 & 14 & 9 & 13 & 32 & 28 & 25 & 8 & & & \\
\hline $21-30$ & & & & & & & & & & & 4 & 9 & 13 & 9 & 5 & & & & & & \\
\hline $31-50$ & & & & & & & & & & & & & & 4 & & 5 & 6 & & & & \\
\hline $51-75$ & & & & & & & & & & & & & & & 5 & & & & & & \\
\hline
\end{tabular}

Table 19. Recurrence of the decadal height of snow cover by decades at Bobrynets station for the period 1996-2018 (\%)

\begin{tabular}{|c|c|c|c|c|c|c|c|c|c|c|c|c|c|c|c|c|}
\hline \multirow[t]{2}{*}{ Gradation } & \multicolumn{3}{|c|}{$\mathrm{XI}$} & \multicolumn{3}{|c|}{ XII } & \multicolumn{3}{|c|}{ I } & \multicolumn{3}{|c|}{ II } & \multicolumn{3}{|c|}{ III } & \multirow{2}{*}{$\begin{array}{c}\text { IV } \\
1 \\
\end{array}$} \\
\hline & 1 & 2 & 3 & 1 & 2 & 3 & 1 & 2 & 3 & 1 & 2 & 3 & 1 & 2 & 3 & \\
\hline $0-5$ & 100 & 100 & 75 & 91 & 93 & 83 & 69 & 66 & 41 & 48 & 68 & 69 & 50 & 60 & 88 & 100 \\
\hline $6-10$ & & & 25 & 9 & 7 & 17 & 13 & 6 & 11 & 19 & 6 & 6 & 8 & 10 & 12 & \\
\hline $11-20$ & & & & & & & 12 & 22 & 27 & 19 & 10 & 6 & 17 & 30 & & \\
\hline $21-30$ & & & & & & & 6 & 6 & 21 & 5 & 5 & 19 & 25 & & & \\
\hline $31-50$ & & & & & & & & & & 9 & 11 & & & & & \\
\hline
\end{tabular}

in the gradation of $51-75 \mathrm{~cm}$, recorded in the third was recorded in the third decade of November - $25 \%$. decade of February with a recurrence of 5\% only The maximum recurrence in the gradation of 11-20 according to climatic norms. $\mathrm{cm}-30 \%$ of cases, was in the second decade of March.

At the station Bobrynets the largest values of The highest recurrence-25\%, in the gradation of 21recurrence were observed in the gradation of $0-5 \mathrm{~cm} 30 \mathrm{~cm}$ was observed in the first decade of March.

Table 20. Recurrence of the decadal height of snow cover by decades at Bobrynets station for the period 1961-1990 (\%)

\begin{tabular}{|c|c|c|c|c|c|c|c|c|c|c|c|c|c|c|c|c|c|c|}
\hline \multirow[t]{2}{*}{ Gradation } & \multirow{2}{*}{$\frac{X}{3}$} & \multicolumn{3}{|c|}{ XI } & \multicolumn{3}{|c|}{ XII } & \multicolumn{3}{|c|}{ I } & \multicolumn{3}{|c|}{ II } & \multicolumn{3}{|c|}{ III } & \multicolumn{2}{|c|}{ IV } \\
\hline & & 1 & 2 & 3 & 1 & 2 & 3 & 1 & 2 & 3 & 1 & 2 & 3 & 1 & 2 & 3 & 1 & 2 \\
\hline $0-5$ & 100 & 100 & 83 & 87 & 83 & 79 & 84 & 61 & 47 & 55 & 47 & 49 & 45 & 47 & 64 & 92 & 100 & 50 \\
\hline $6-10$ & & & 17 & 13 & 17 & 21 & 8 & 35 & 45 & 26 & 35 & 8 & 17 & 14 & 18 & 8 & & 50 \\
\hline $11-20$ & & & & & & & 8 & 4 & 4 & 15 & 14 & 31 & 17 & 29 & 12 & & & \\
\hline $21-30$ & & & & & & & & & & & & 8 & 13 & 5 & 6 & & & \\
\hline $31-50$ & & & & & & & & & 4 & 4 & 4 & 4 & 8 & 5 & & & & \\
\hline
\end{tabular}


The gradation of $31-50 \mathrm{~cm}$ was fixed in the first and second decades of February. The appearance of snow cover was recorded in the first decade of November, in contrast to the climatic norm, where the appearance of snow was observed in the third decade of October (Table 20). The disappearance was observed in the first decade of April, which occurred one decade earlier than in the period 1961-1990. The maximum frequency was observed in the gradation of $0-5 \mathrm{~cm}$ and is $100 \%$, can be observed in different decades. The maximum height was recorded in the gradation of $31-50 \mathrm{~cm}$, was fixed in different decades and ranged from 4 to $11 \%$ in different periods.

\section{Conclusions.}

Analysis of snow cover in Kirovohrad region makes it possible to say that at the beginning of the XXI century there were changes in the formation of snow cover. In the last few decades in the west and south of the region, snow cover has formed a decade later than according to climatic norms. Disappearance of snow was determined in the third decade of April in the north of the region, in contrast to the period of the second half of the twentieth century, when disappearance of snow was observed almost throughout the region in the second decade of April. At Kropyvnytskyi station, located in the central part of the Kirovohrad region, the appearance and disappearance of snow cover are determined within the same limits for the two periods. The height of snow at the beginning of the XXI century decreased both in terms of averages and extremes. The frequency of winters with the highest decadal height of snow cover in different gradations varies greatly in the study periods. For 1996-2018, the maximum was observed in the gradation of $1-5 \mathrm{~cm}$, significant recurrence was found for a height of $0 \mathrm{~cm}$; in the climatic norm the greatest recurrence was recorded in the gradation of $11-20 \mathrm{~cm}$, significant indicators were observed in the gradation of 21-30 cm of snow cover. The maximum recurrences of the decadal height of the snow cover are $100 \%$. They are defined in the gradation of $0-5 \mathrm{~cm}$ in both periods at the beginning and end of the period with snow cover.

\section{References}

Aoki, T., Hachikubo, A., Hori, M., 2003. Effects of snow physical parameters on shortwave broadband albedos. J. Geophys. Res., 108 (D19). 4616. doi:10.1029/2003JD003506.

Encyklopedija suchasnoi Ukrainy. Retrieved from http:// esu.com.ua/search_articles.php?id=7021
Goroshko, V.V., 2017. Snigovyj pokryv jak faktor vplyvu na zhyttjedijalnist myslyvskoi fauny Harkivshhyny [Snow cover as a factor influencing the vital activity of the hunting fauna of Kharkiv region]. Naukovyj visnyk NLTU Ukrainy. 27(6), 25-28 (in Ukrainian).

Klimatologichni standartni normy (1961-1990 rr.), 2002. [Climatological standard norms (1961-1990)]. UkrNDGMI-CGO, Kyiv (in Ukrainian).

Kornus, A.O., Lysenko, I.O., 2017. Harakterystyka snigovogo pokryvu Sumskoi oblasti za rezultatamy sposterezhen 2005-2017 rokiv [Characteristics of the snow cover of Sumy region according to the results of observations of 2005-2017]. Naukovi zapysky SumDPU imeni A.S. Makarenka. Geografichni nauky. 8, 3-6 (in Ukrainian).

Lebedenko, A., 2019. Analiz klimatychnyh ta statystychnyh harakterystyk snigovogo pokryvu na stancijah Kirovogradskoi oblasti [Analysis of climatic and statistical characteristics of snow cover at stations of Kirovohrad region]. Zbirnyk naukovyh robit XVI Mizhnarodnoi naukovo-praktychnoi internet-konferencii «Problemy ta perspektyvy rozvytku suchasnoi nauky $\mathrm{v}$ krainah Jevropy ta Azii». Perejaslav-Hmelnyckyj. 21-23 (in Ukrainian).

Lebedenko, A.I., Nedostrelova, L.V., 2018. Osoblyvosti chasovoi minlyvosti snigovogo pokryvu na stancijah Kirovogradskoi oblasti [Features of temporal variability of snow cover at stations of Kirovohrad region]. Vestnyk GMC ChAM. 2(22), 100-107 (in Ukrainian).

Lebedenko, A.I., Nedostrelova, L.V., 2019. Doslidzhennja klimatychnyh pokaznykiv snigovogo pokryvu na terytorii Kirovogradskoi oblasti [Research on climatic indicators of snow cover in the territory of Kirovograd region]. Materialy VII Mizhnarodnoi naukovo-praktychnoi internetkonferencii «Suchasnyj ruh nauky». Dnipro. 992995 (in Ukrainian).

Lebedenko, A.I., Nedostrelova, L.V., 2019. Prostorova minlyvist povtorjuvanosti dekadnoi vysoty snigovogo pokryvu po dekadah na stancijah Kirovogradskoi oblasti [Spatial variability of recurrence of decadal height of snow cover by decades at stations of the Kirovograd region]. Vestnyk GMC ChAM. 23, 42-52 (in Ukrainian).

Nastanova gidrometeorologichnym stancijam i postam, 2011. [Guidelines for hydrometeorological stations and posts]. Vypusk 3. Chastyna I. Derzhavna gidrometeorologichna sluzhba, Kyiv, 91-95 (in Ukrainian).

Nedostrelova, L., Lebedenko, A., 2018. Doslidzhennja prostorovoi minlyvosti snigovogo pokryvu na terytorii Kirovogradskoi oblasti [Study of spatial variability of snow cover in Kirovohrad region]. International science journal «Polish Science Journal». 7, 18-26 (in Ukrainian). 
Nedostrelova, L., Lebedenko, A., 2019. Harakterystyka klimatychnyh pokaznykiv snigovogo pokryvu na terytorii Kirovogradskoi oblasti [Characteristics of climatic indicators of snow cover in the Kirovohrad region]. International science journal «Polish Science Journal». 19, 23-28 (in Ukrainian).

Nedostrelova, L.V., Lebedenko A.I., 2019. Prostorovyj rozpodil povtorjuvanosti zym $\mathrm{z}$ riznoju najbilshoju dekadnoju vysotoju snigovogo pokryvu na terytorii Kirovogradskoi oblasti [Spatial distribution of winter recurrence with different maximum decadal height of snow cover in Kirovohrad region]. Abstracts of I International Scientific and Practical Conference. Vancouver, Canada, 202-207 (in Ukrainian).
Nedostrelova, L.V., Lebedenko, A.I., 2019. Doslidzhennja povtorjuvanosti dekadnoi vysoty snigovogo pokryvu po dekadah na stancijah Kirovogradskoi oblasti [Study of the frequency of decadal height of snow cover by decades at stations in Kirovohrad region]. XIII Mizhnarodna naukova konferencija «Perspectives of Science and Education». Nju Jork, SShA, 319-325 (in Ukrainian).

Spravochnyk po klymatu SSSR. Vypusk 10, 1969. [Guide to the climate of the USSR]. Gydrometeoyzdat, Lenyngrad (in Russian).

Vrublevska, O.O., Katerusha, G.P., Myrotvorska, N.K., 2004. Klimatychna obrobka okremyh meteorologichnyh velychyn [Climatic treatment of individual meteorological quantities]. TES, Odesa (in Ukrainian). 